\title{
Rewarding Female Commanders in Medieval China: Official Documents, Rhetorical Strategies, and Gender Order*
}

\author{
Shoufu Yin* (D) \\ Department of History, University of California Berkeley, USA \\ ${ }^{*}$ Corresponding author. Email: shoufu.yin@ubc.ca
}

(Received 21 May 2020; revised 25 June 2021; accepted 17 July 2021)

\begin{abstract}
Much of our knowledge of women and warfare in medieval China comes from biographical/ narrative genres of a retrospective nature. This article shifts the focus to an underutilized corpus: imperial documents conferring titles and rewards on women who commanded troops. I examine how the court described these women when it came to honor them, or even when it sought their support through real-time negotiation. In these cases, the recognition of women's achievements was conditioned not only by deep cultural/literary traditions but also by immediate political/military goals of the regime. As a result of the concrete political need to engage with female commanders, medieval Chinese courts deployed different approaches to eulogize them. My investigation shows that closer dialogue between gender studies and official document studies will lead to a more dynamic picture of how a patriarchal regime actually functioned in premodern China.
\end{abstract}

Keywords: female commanders; medieval China; Ch'oe Ch'i-wŏn; edicts and official documents; rhetoric

\section{Introduction}

From the Disney animated film Mulan (1998) to the video game Total War: Three Kingdoms (2019), contemporary popular culture has staged medieval (ca. 200-1000 $\mathrm{CE})$ Chinese stories of women in war for the global audience. ${ }^{1}$ Behind these legendary tales, however, there is an under-recognized history of Chinese women who assumed leadership in violent settings. ${ }^{2}$ They engaged in fighting, mounted and on foot. They

${ }^{\star}$ I am much indebted to Nicolas Tackett for his detailed suggestions on every draft of this article, and to Beverly Bossler for her guidance throughout the process. I am very grateful for the criticism that the anonymous reviewers have provided. I thank Michael Nylan, Robert Ashmore, Geoffrey Koziol, Yiqun Zhou, Jianye He, Joseph Passman, Elisheva Wyle, and Chuxu Lu for their insightful comments and continuous support.

${ }^{1}$ For the case of Zheng Jiang 鄭姜, the woman rebel leader as imagined in the Total War, see https:// totalwar.fandom.com/wiki/Zheng_Jiang, accessed on March 12, 2021. For the term medieval China, see Charles Holcombe, "Was Medieval China Medieval? (Post-Han to Mid-Tang)," in A Companion to Chinese History, edited by Michael Szonyi (London: Blackwell, 2017), 106-17.

${ }^{2} \mathrm{An}$ increasing number of studies have shown that Chinese women played active roles in warfare during different historical periods. See Bret Hinsch, Women in the Tang (London: Rowman \& Littlefield, 2019),

(C) The Author(s), 2021. Published by Cambridge University Press. This is an Open Access article, distributed under the terms of the Creative Commons Attribution licence (http://creativecommons.org/licenses/by/4.0/), which permits unrestricted re-use, distribution, and reproduction in any medium, provided the original work is properly cited. 
mobilized troops, in numbers large or small. ${ }^{3}$ As the boundaries between politics and warfare remained particularly porous in medieval China, these women came to wield substantial degrees of overt authority beyond a rigid civil/military divide. ${ }^{4}$ For this reason, I use the etic term "female commanders" to cover a wide range of women who led in different contexts of violence, from military campaigns to palace coups d'état.

Previous research has shown how the literary-historical tradition of imperial China has retrospectively reconstructed female commanders, adapting their deeds into episodes more or less palatable to preexisting conceptions. ${ }^{5}$ Absent from existing scholarship, however, is an examination of how the court described female commanders when it rewarded them with titles, honors, and other benefits, or even when it sought their support through real-time negotiation. In other words, when the regime was obliged to promote female commanders, how would it phrase its documents addressing these women? Focusing on these cases, I show that medieval courts were not ideologically rigid, sticking to a single set of models of proper female behavior-that women should always be submissive and serve men of the family. Instead, the courts deployed distinct rhetorical tools to eulogize individual female commanders; taking into account the particularities of the situation, they eulogized these women to pursue specific political goals. Thus, the rhetoric these courts used provides critical insight into the ways by which Chinese empires interpreted and reacted to women's successes in the midst of concrete military and political crises, and will thus help us to understand how the patriarchal regimes actually worked in times of turmoil.

While biographical genres are important sources of medieval Chinese history that no researcher can afford to overlook, this article focuses on an alternative corpus: edicts and other official documents (including orders and court-issued letters) rewarding female commanders with privileges, titles, ranks, and incomes. ${ }^{6}$ These documents, which leave us records of real-time politics, have long evaded scholarly attention, partly because the texts survive for contingent reasons and in a number of different forms, so that serious effort is required to identify them. Here I bring together, for the first time, edicts and official documents culled from a variety of sources, ranging from collections surviving in Korea to archival materials from the imperial chancellery (see the Appendix). Reading them in the context of and in comparison with biographical and historical writings of different genres, I identify three ideal-type strategies of representing female commanders.

I start by identifying a key strategy by which biographies and other sources describe female commanders. This strategy, which I call the reductionist approach, eulogizes female commanders by reducing them to filial daughters or faithful wives, who temporarily transgress gender boundaries only to better fulfill more important responsibilities

esp. 39-58; Linda Cooke Johnson, Women of the Conquest Dynasties: Gender and Identity in Liao and Jin China (Honolulu: University of Hawai'i Press, 2011), esp. 121-40; Shi Houyu 施厚羽, Jinguo ru rongshi: Jin Tang jian de zhanzheng yu xingbie 巾幗入戎事:晉唐間的戰爭與性別 (Taipei: Daoxiang, 2020), passim.

${ }^{3}$ In the tumultuous 880 s, for instance, the well-documented provincial center of Huainan witnessed the rise of at least two women, each of whom led troops on her own, attacking or defending fortifications. See sections below.

${ }^{4}$ See Michael Nylan and Shoufu Yin, "Wen and wu: Reading the Sunzi in Historical Context," in Norton Critical Edition of Sun Tzu, edited by Michael Nylan (New York: W. W. Norton, 2021).

${ }^{5}$ See Rebecca Doran, Transgressive Typologies: Construction of Gender and Power in Early Tang China (Cambridge: Harvard University East Asian Center, 2017), esp. 33; cf. Roland Altenburger, The Sword or the Needle: The Female Knight-errant (xia) in Traditional Chinese Narrative (Bern: Peter Lang, 2009).

${ }^{6}$ For different types of edicts, see Enno Giele, Imperial Decision-making and Communication in Early China: A Study of Cai Yong's Duduan (Wiesbaden: Harrassowitz, 2006), 250-80; cf. Nakamura Hiroichi 中村裕一, Tōdai kōbunsho kenkyū 唐代公文書研究 (Tōkyō: Kyūko shoin, 1996). 
that the patriarchal order prescribes for them. Then, turning to edicts that have survived in different places, I argue that the imperial court of the seventh and eighth centuries sometimes portrayed female leaders as exceptional individuals who transcended the gender order prescribed to commoners-an approach that I call the transcendent strategy. Last but not least, I examine a set of official documents dating to ca. 883, when Ch'oe Ch'i-wŏn 崔致遠 (857-ca. 908), ${ }^{7}$ a native of Silla Korea, was crafting orders on behalf of the provincial government of Huainan. I propose that in the particular circumstances of the 880s, Ch'oe resorted to an eclectic approach. He endeavored to reconcile, rhetorically or philosophically, women's subordinate roles in the family and their leadership on the battlefield, seeking to find a middle ground to justify their simultaneous military valor and wifely virtues. ${ }^{8}$ In the end, highlighting the fact that a variety of women-related edicts and official documents remain understudied, I close this article by showing that late imperial regimes continued to exploit the rhetorical strategies that their medieval predecessors had developed.

\section{Female Commanders as Filial Daughters/Chaste Wives}

This section introduces literary tropes by which medieval authors retrospectively re-described women in war. Since early times, genres ranging from official dynastic histories to poems and tales sought to justify female leadership in war by highlighting the heroine's resolve to rescue, to aid, or to avenge her father or husband. This rhetoric contrasts with that embedded in real-time political negotiations, which we shall examine in subsequent sections.

Women in warfare have a long history in China. Since at least the first century BCE, dynastic histories identified a variety of women that led their own troops into war, though it was usually during periods of dynastic change that female leaders came to public notice. ${ }^{9}$ These women included Mother Lü 吕母 (d. $\left.18 \mathrm{CE}\right)$, Chi Zhaoping 迟昭平 (ca. $21 \mathrm{CE}$ ), and Chen Shuozhen 陳碩真 (ca. $653 \mathrm{CE}) .{ }^{10}$ Not surprisingly, the dynastic histories featured their rebellion against the political order by highlighting their transgression of the gender hierarchy. This, however, does not mean that normative texts of early China always castigated women who participated or led in warfare. From different perspectives, Anne Cheng and Luo Manling have shown that poems and verses of Han times and of the following centuries sometimes eulogized filial daughters who avenged their husbands or fathers, even though vengeance remained a controversial matter in legal debates. ${ }^{11}$ Against this backdrop, it is not surprising

\footnotetext{
${ }^{7}$ For recent studies in Korean, see, for instance, Kim Pok-sun (金福順), Ch'oe Ch'i-wŏn ŭi yŏksa insik $k w a$ Silla munhwa 최치원 의 역사 인식 과 신라 문화 (Kyŏnggi: Kyŏngin Munhwasa, 2016).

${ }^{8}$ Though I proceed chronologically, I do not mean that the three ideal-types were chronologically developed one after another.

${ }^{9}$ Transmitted texts have shown that no later than 589 BCE women were granted land settlements for their deeds in military crises. See Stephen Durant et al., Zuo Tradition/Zuozhuan (Seattle: University of Washington Press, 2016), 720. For the legend of Sunzi turning palace women into soldiers, see Benjamin Daniels, "Killing the King's Concubines: Sunzi and the Kingdom of Wu," in Sunzi: Norton Critical Edition.

${ }^{10}$ See also Fan Ye 范瞱, Hou Han shu 後漢書 (Beijing: Zhonghua shuju, 1965), juan 11, 477; Zizhi tongjian, juan 199, 6282.

${ }^{11}$ Anne Cheng, "Filial Piety with Vengeance," in Filial Piety in Chinese Thought and History, edited by Alan Chan and Sor-Hoon Tan (London: Routledge, 2004), 29-43; Luo Manling, "Gender, Genre, and Discourse: The Woman Avenger in Medieval Chinese Texts," Journal of the American Oriental Society 134.4 (2014), 579-99.
} 
that biographical writings eulogized-and criticized-female commanders based on the criterion of whether/how they aided their fathers or husbands.

The "Biographies of Women" in Jin shu 晉書 (History of Jin, finalized in 648) provide various interesting examples of praiseworthy women who led troops and/or fought in person. One entry details how in the tumultuous 300s, when the Western Jin (266-316) fell, Xun Guan荀灌 (ca. 316), a thirteen-year-old girl, stood out from the crowd:

Xun Song's young daughter was [Xun] Guan. Since her childhood, Guan was outstanding in terms of moral character. When Song was Governor of Xiangcheng, he was besieged by Du Ceng. Weak in military force, and with food provisions exhausted, he wanted to seek help from his previous subordinate Shi Lan, the General Pacifying the South, but he could not find a way [to get out of Xiangcheng]. Guan was thirteen by then. She thus commanded several dozens of warriors; they passed over the walls, broke through the siege, and went out for help at night.

荀崧小女灌, 幼有奇節。崧為襄城太守, 為杜曾所圍, 力弱食盡, 欲求救 於故吏平南將軍石覽, 計無從出。灌時年十三, 乃率勇士數十人, 踰城突 圍夜出 $\ldots . . .12$

The Jin shu narrative is unambiguous in justifying why Xun Guan "commanded warriors"she did so for the sake of seeking reinforcements to rescue her beleaguered father. What it leaves out, of course, is how she actually led and fought. To cite another example, in 402, Xie Daoyun 謝道喡 (ca. 399), whose talents in poetry are well known, also engaged in fighting. As Jin shu describes it, "after she heard that her husband and sons were slaughtered by the bandits," she led her servants into blade-to-blade battle, and "killed several bandits with her own hands before she was captured." ${ }^{3}$ Though the Jin shu account briefly describes the fighting, the narrative gravity focuses on the fact that she resorted to fighting only to defend her household and herself, after the bandits forced themselves into her domestic space.

During Xun Guan and Xie Daoyun's times, a variety of groups originating from the Eurasian Steppe started to build their own regimes in north China. Jin shu provides a vivid account of how Empress Mao 毛皇后 (?-389), a woman of Di 氏 ethnic origin, led troops into battle:

Strong and courageous, she excelled in mounted archery. When Fu Deng was attacked by Yao Chang, his camp fell. Ms. Mao was still bending her bow on horseback. Leading several hundred warriors, she fought against Chang and imposed heavy casualties upon her enemy. Greatly outnumbered, she was captured by Chang. Chang wanted to take her. She railed: "I am the Empress of the Son of Heaven [i.e. Fu Jian (338-385)]. How can I bear to be humiliated by a Qiang barbarian bandit? Why not kill me immediately!" Then, facing heaven, she burst into tears: "Yao Chang violated the Way: previously he murdered the Son of Heaven (that is, Fu Jian); now he humiliates the Empress. Oh, August Heaven and the Grand Earth, how can you not see what is happening?" Angered, Chang killed her.

壯勇善騎射。登為姚萇所襲，營壘既陷，毛氏猶彎弓跨馬，率壯士數百 人, 與萇交戰, 殺傷甚眾。眾臭不敵, 為萇所執。萇欲納之, 毛氏罵曰:

\footnotetext{
${ }^{12}$ Fang Xuanling 房玄齡 et al., Jin shu 晉書 (Beijing: Zhonghua shuju, 1974), juan 96, 2515.

${ }^{13}$ Fang Xuanling et al., Jin shu, juan 96, 2516.
} 
「吾天子后，豈為賊㒸所辱？何不速殺我！」因仰天大哭曰：「姚萇無道， 前害天子，今辱皇后，皇天后土，寧不鑒照！」萇怒，殺之。 ${ }^{14}$

It is important to note that this narrative fails to inform readers that Fu Deng, on campaign elsewhere, had left Ms. Mao in charge of the camp. ${ }^{15}$ Specifically, it deletes a crucial line found in earlier sources that explains that " $[\mathrm{Fu}]$ Deng left Ms. Mao and the supplies at the camp." ${ }^{16}$ In fact, with Fu Deng's young son under her care, Empress Mao was among the most important decision makers on site. The Jin shu biographical entry, however, directs readers' attention away from Empress Mao's leadership role. Instead, it suggests that Ms. Mao was confined to her domestic space in the camp, and, much like Xie Daoyun, resorted to fighting only because she had no other choice. What the narrative focuses on, in the end, is her resolution to die for a righteous cause (from the perspective of the medieval author) - namely, the rejection of a humiliating remarriage or even rape. In this sense, the biography shapes a story of female military command into the story of a faithful wife, which better fits patriarchal conventions of women's behavior.

There are many similar examples in dynastic histories and narrative poems. By far the best-known case can be found in Mulan shi 木蘭詩 (Ballad of Mulan). According to this tale, which arguably originated from stories of the sixth or seventh century, Mulan joined the army only with the goal of exempting her aged father from military conscription. ${ }^{17}$ But there are other examples as well. Yang Dayan's 楊大眼 (fl. early sixth century) biography in Wei shu 魏書 (The dynastic history of the Northern Wei) informs us that his wife Ms. Pan 潘氏 was noted for her skills in mounted archery. However, according to the biography, "[Yang] Dayan ordered his wife to dress in military clothing” (大眼令妻潘戎裝) and to join him in charging on horseback. In other words, the narrative portrays her as someone who entered the battlefield only when her husband ordered her to do so. ${ }^{18}$ As we shall see below, Tang female commanders were also often portrayed as followers of a male family member in their biographies in dynastic histories. However, in the heat of the moment in the midst of complicated political necessities that the aforementioned biographers-writing in retrospect-did not face, the authors of edicts and other official documents deployed somewhat different rhetoric, which the following sections examine.

\section{Female Commanders as Exceptions to Patriarchal Rule}

While Jin shu illustrates how early Tang litterateurs depicted female commanders who fought centuries earlier in terms of existing models of proper female behavior, this

\footnotetext{
${ }^{14}$ Fang Xuanling et al., Jin shu, juan 96, 2523. For an account with minor variations, see Sima Guang 司馬光 et al., Zizhi tongjian 資治通鑑 (Beijing: Zhonghua shuju, 1956) [hereafter ZZT]], juan 107, 3441.

${ }^{15}$ Fang Xuanling et al., Jin shu, juan 115, 2951.

${ }^{16}$ That is, Shiliuguo chunqiu 十六國春秋 (Spring and autumn of sixteen kingdoms), see Cui Hong 崔鴻, Shiliuguo chunqiu jibu 十六國春秋輯補 (Beijing: Zhonghua shuju, 2019), juan 40, 530. Evidential scholars of the Qing (1644-1911) tended to believe that Tu, the Ming editor, reconstructed, if not entirely reinvented, the Shiliuguo chunqiu that he published. Some recent scholars, however, argue that Tu did use various earlier sources when compiling this work. See Liu Guoshi 劉國石, “Qingdai yilai tu ben Shiliuguo chunqiu yanjiu zongshu” 清代以來屠本十六國春秋研究綜述, Zhongguoshi yanjiu dongtai 中國史研究 動態 8 (2008), 10-15.

${ }^{17}$ For Mulan shi, see Guo Maoqian 郭茂倩 ed., Yuefu shiji 樂府詩集 (Beijing: Zhonghua shuju, 1979), juan 25, 373; Joseph R. Allen, "Dressing and Undressing the Chinese Women Warrior," Positions 4.2 (1996), 343-79.

${ }^{18}$ Wei Shou 魏收, Wei shu 魏書 (Beijing: Zhonghua shuju, 1959), juan 73, 1634.
} 
section turns to examine how the court of the seventh and early eighth centuries conferred titles and rewards on contemporary women. Though the early Tang is noted "for relatively few restrictions and oppressive measures on women," this does not mean that women of high social status were "entirely free to move about in public places," much less lead military forces. ${ }^{19}$ Even during the decades of female (co-)rulership of the empire (ca. 664 to 713), ${ }^{20}$ many-if not most-imperial documents adhered to a rhetoric that in no way undermined the patriarchal worldview. Instead, the court portrayed female leaders not as exemplary figures according to established gender norms, but as transcendent figures who rose above the gender norms prescribed to commoners. ${ }^{21}$ In other words, vis-à-vis women's success in military leadership, the edicts that we shall read repeatedly emphasized that these women were exceptions because they were imperial princesses, and exceptional ones at that.

Princess Pingyang (?-623) affords the natural starting point for an inquiry into Tang female commanders. Like the female rebel leaders of earlier centuries, she built her own army when the political order broke down. As her biography in Jiu Tang shu 舊唐書 (Old history of the Tang) explains, "she used the family property to recruit men at large in the mountains"-an act that, as it was usually associated with male leadership in times of turmoil, also attested to her power in disposing of property. ${ }^{22}$ Eventually, she gathered an army reported to number about 70,000 soldiers. ${ }^{23}$ As her biography illustrates, thanks to her effective military actions (alongside those of her brothers), her father Li Yuan 李淵 (Tang Gaozu, 566-635, r. 618-626) was able to seize Chang'an and declare himself emperor of the new Tang Dynasty. ${ }^{24}$ When Princess Pingyang died in 623, Li Yuan ordered that her burial ceremony should include processional music of the army composed of drums and fifes, known as guchui 鼓吹. The Bureau of Rites objected to this, arguing that the honor of having drums and fifes in one's burial ceremony was reserved for men. But Gaozu, in his edict, proposed a different interpretation. According to her biography in Jiu Tang shu:

\section{Emperor Gaozu replied:}

\footnotetext{
${ }^{19}$ Altenburger, The Sword or the Needle, 68.

${ }^{20}$ In 664, Wu Zhao 武龳 (that is, Wu Zetian 武則天), by then the empress of Gaozong, was able to execute the ministers who advised the emperor to take action against her. In 713, Princess Taiping fell. During the intervening period, a variety of women-Wu Zhao, Empress Wei, Princess Anle, and Princess Taiping, to name a few-were at the pinnacle of political power at the court. For a narrative history, see R. W. L. Guisso, "The Reigns of the Empress Wu, Chung-tsung and Jui-tsung," in The Cambridge History of China, vol. 3, edited by Denis C. Twitchett (Cambridge: Cambridge University Press, 1979), 290-332.

${ }^{21}$ It is worth mentioning that male elites sometimes employed a similar transcendent strategy, seeking to exempt themselves from the normative order. Famously, Ruan Ji 阮籍 (210-263) once asked rhetorically, “Were the rites established for people like me?” (禮豈為我輩設也). See Xu Zhen'e 徐震堮, Shishuo xinyu jiao jian 世說新語校箋 (Beijing: Zhonghua shuju, 1984), juan 23, 393. In this episode, Ruan was not denying the validity of rites, but proclaiming his own transcendence over them.

${ }^{22} \mathrm{Liu} \mathrm{Xu}$ 劉㽛 et al., Jiu Tang shu 舊唐書 (Beijing: Zhonghua shuju, 1975), juan 58, 2316. On steppe influence upon early Tang political culture, see Jonathan Karam Skaff, Sui-Tang China and Its Turko-Mongol Neighbors: Culture, Power, and Connections, 580-800 (Oxford: Oxford University Press, 2012), 39.

${ }^{23}$ With regard to the violence of the warfare of this period, see Yang Shao-yun, "Letting the Troops Loose: Pillage, Massacres, and Enslavement in Early Tang Warfare," Journal of Chinese Military History 6 (2017), 1-52.

${ }^{24}$ For Li Yuan's advance to Chang'an, see Woodbridge Bingham, The Founding of the T'ang (Baltimore: Waverly Press, 1941), 95-103.
} 
(I) Fife and drum is the music of the army. (II) Previously, the Princess raised troops at Sizhu to join the righteous campaign; [by then,] she controlled the signal gongs and drums [that is, she herself gave orders of retreat and attack to the army]. She has the merit of pacifying the realm. Mother Wen of Zhou is among the Ten Worthies [who helped King Wu establish the Zhou.] The Princess, [likewise,] has contributed to the founding of the imperial enterprise. She was not simply one of the ordinary women! (III.1) How can her [burial ceremony] be without fife and drum?

(III.2) Thus, the court added fife and drum for her as an exception, so as to honor her exceptional achievements.

Under Gaozu's order, the bureau in charge followed the posthumous naming rule that "those with illustrious virtues who have rendered great service will be called Zhao [literally, Bright]," and so endowed her with the posthumous name of Zhao.

高祖曰：鼓吹，軍樂也。往者公主於司竹舉兵以應義旗，親執金鼓，有克 定之勳。周之文母, 列於十亂, 公主功參佐命, 非常婦人之所匹也! 何得 無鼓吹? 遂特加之，以旌殊績 ; 仍令所司按湓法「明德有功曰昭」，湓公主 為昭。 25

Based very closely on an original imperial speech, this text thus well attests to the mentality at court in 623, when the court added fife and drum for Princess Pingyang. By then, although the Tang had triumphed over its major opponents in the Chinese heartland, it was still facing substantial challenges from rebels in recently conquered regions, not to mention the threat posed by the Eastern Türk confederation. ${ }^{26}$ Against this backdrop, the allusion to "Mother Wen of Zhou" commands particular attention. In the chapter of the Grand Proclamation (tai shi 泰誓) of the Shangshu 尚書 (Classic of Documents), King $\mathrm{Wu}$ of Zhou, having summoned all the troops, illustrated various reasons for which the Zhou was destined to conquer the Shang. One of the reasons articulated was that “We have ten worthy ministers" (予有亂臣十人), among whom

\footnotetext{
${ }^{25}$ Liu Xu et al., Jiu Tang shu, juan 58, 2316. Though this passage is excerpted from Princess Pingyang's dynastic history biography, formal analysis strongly suggests that the historian derived the passage from an edict that no longer survives. The passage adheres almost perfectly to the formulaic structure of an imperial edict endowing privileges, titles, or rewards to its recipients, as I have sought to suggest by marking the parts with the sequence (I) to (III), in accordance with a system that I have previously devised for analyzing such edicts. Part (I) starts with a general statement about the relevant principle-in this case of when to use drums and fifes; part (II) then moves to detail the subject's (here Princess Pingyang) contributions; finally, part (III) concludes the argument by stating that, given the principle of when to use drums and fifes in conjunction with Princess Pingyang's demonstrated merit, the decision follows as a logical consequence. This polished language loaded with historical allusion to Zhou times (ca. 1040-256 BCE), along with the organization of the text, reveals that the compiler of this biography was paraphrasing a written edict in the imperial archive, which was a common practice in the composition of Jiu Tang shu biographies. For further discussion on how dynastic histories in medieval China cited and paraphrased imperial documents, see Nie Weimeng 聶溦萌, Zhonggu guanxiushi tizhi de yunzuo yu yanjin 中古官修史體制的運作 與演進 (Shanghai: Fudan daxue chubanshe, 2021), esp. 3, 67.

${ }^{26}$ Sima Guang et al., ZZTJ, juan 190, 6092. For the changing relationship between the Turks and the Tang during the early seventh century, see Skaff, Sui-Tang China and Its Turko-Mongol Neighbors, 8-17; Wang Zhenping, Tang China in Multi-Polar Asia: A History of Diplomacy and War (Honolulu: University of Hawai'i Press, 2017), 11-39.
} 
was Mother Wen of Zhou. ${ }^{27}$ Eulogizing Princess Pingyang in terms of Mother Wen, the "worthy minister," the imperial speech confirms that the boundaries between "minister" and "general," civil and military, were particularly porous in the early Tang context. Equally importantly, the document thus likened the Li family of the Tang to that of King Wen of Zhou, implying that the founding of the Tang was comparable with that of the exemplary dynasty of the Zhou.

One should note in addition that the speech makes it clear that Princess Pingyang was a key commander who gave orders of attack and retreat by controlling "the signal gongs and drums," another trope commonly associated with male commanders-inchief. $^{28}$ In other words, far from reducing Princess Pingyang to a mere follower of her husband or her father, the imperial speech employed an alternative rhetoric that staged her as an exceptional woman. The description of Princess Pingyang was thus in accordance with Emperor Gaozu's political needs at this moment right after the founding of the dynasty. Highlighting the extraordinary achievements of its female members helped reinforce the claim that the Li family was destined to ascend to the throne. More generally, by recognizing the formula of imperial edicts within dynastic biographies, we can begin to see how imperial speech-shaped by contemporaneous political exigencies-could differ from the more conventional moral glossings of dynastic-history authors.

Princess Pingyang was by no means the only female leader in war and politics during the seventh century. ${ }^{29}$ After 664, Wu Zhao 武曌 (624-705, r. 690-705) came to dominate imperial decision making; from 690 to 705, she ruled China as sovereign. Even after her downfall, her achievements continued to inspire female powerholders like Empress Wei 韋后 (664-710) and a variety of princesses to compete for political power. $^{30}$ These decades of female rule meant that authors in court and beyond developed new rhetorical devices to legitimize these women in power. ${ }^{31}$

To understand how the court honored female leaders who won violent conflicts, I focus on the "Edict Endowing Additional Actual Households of Income to the Princess Guardian of the Realm and of the Great Peace [i.e., Princess Taiping]" 鎮國 太平公主加實封制 (710), a document that has survived in the Tang da zhaoling ji 唐大詔令集 (Collection of grand edicts and decrees of the Tang). As early as 705, Princess Taiping had played an important role in deposing $\mathrm{Wu}$ Zhao to re-establish the Tang dynasty. ${ }^{32}$ Five years later, she mobilized imperial troops to lead another coup d'état, together with her nephew Li Longji 李隆基 (685-762, r. 712-756), better known for his lengthy reign as Emperor Xuanzong. At that time, however, her nephew

\footnotetext{
${ }^{27}$ Shangshu zhengyi 尚書正義 (Beijing: Beijing daxue, 1999), 328.

${ }^{28}$ For instance, Cao Cao 曹操 (155-220) was described as "hitting the gongs and drums on his own, ordering the advance and retreat of the troops." See Chen Shou, Sanguo zhi, juan 1, 49.

${ }^{29}$ Interestingly, following the precedent of Princess of Pingyang, an edict of 708 authorized the use of fife and drum on the burial day of all imperial concubines and princesses. See Wang Pu 王溥, Tang huiyao 唐會要 (Shanghai: Shanghai guji, 2006), juan 85, 2813.

${ }^{30}$ See Guisso, “The Reigns of the Empress Wu, Chung-tsung and Jui-tsung."

${ }^{31}$ Rhetoricians of the court had portrayed the female monarch in a variety of ways, ranging from the Sage Mother qua the August Sovereign of the realm to the Buddhist Wheel-Turning Ruler. See Antonino Forte, Political Propaganda and Ideology in China at the End of the Seventh Century (Naples: Istituto universitario orientale, 1976), 167. Female authors, it should be noted, themselves contributed to the rise of this new imperial rhetoric. Rebecca Fu, "Women's Literacy Practices in Late Medieval China (600-1000)" (PhD diss., University of Pennsylvania, 2015), 107-18.

${ }^{32}$ Liu Xu et al., Jiu Tang shu, juan 183, 4738.
} 
was only a twenty-six-year-old prince with limited experience at court. The pair executed their rivals and re-enthroned the impotent Emperor Ruizong (662-716) - who was Princess Taiping's elder brother and Li Longji's father. Against this backdrop, the following edict was issued in the name of Ruizong to reward Princess Taiping with additional households of income:

\begin{tabular}{|c|c|}
\hline 門下： & To the Chancellery: ${ }^{33}$ \\
\hline $\begin{array}{l}\text { 功定宗社者, 可以高邁等夷 ; } \\
\text { 事超縑簡者, 故能永昭徽烈。 }\end{array}$ & $\begin{array}{l}\text { (I) The persons who succeed in settling the Temple and the Altar } \\
\text { greatly transcend their peers. The deeds that exceed the scope } \\
\text { of silk-and-bamboo [that is, historical] records forever shine } \\
\text { upon their greatness. }\end{array}$ \\
\hline $\begin{array}{l}\text { 鎮國太平公主 : } \\
\text { 若華分景, 穠李流芳; 以同 } \\
\text { 氣之親, 鍾先朝之愛。忠孝 } \\
\text { 行己, 仁明絕倫。才無不 } \\
\text { 周, 識無不綜。頃夷國難, } \\
\text { 爰戴朕躬, 大義動天, 㤅誠 } \\
\text { 貫日。 }\end{array}$ & $\begin{array}{l}\text { (II) Princess Guardian of the Realm and of the Great Peace: [in } \\
\text { her,] the illustrious blossom shares its luster; the luxuriant } \\
\text { plum exudes its fragrance. As offspring of the same blood, she } \\
\text { enjoyed the love of the previous sovereigns. }{ }^{34} \text { [She is] loyal } \\
\text { and filial in how she conducts herself, and her benevolence } \\
\text { and discernment surpass all others. There is nowhere to } \\
\text { which her talents do not extend, and nothing that her mind } \\
\text { does not grasp. Previously, she resolved the catastrophe } \\
\text { afflicting the Realm; then, she supported Us as the emperor. } \\
\text { Her supreme righteousness moves Heaven; her earnest } \\
\text { sincerity binds her to the sun. }\end{array}$ \\
\hline $\begin{array}{c}\text { 氛禤已廓, 每聽鳴謙之詞 ; 井 } \\
\text { 田未優, 復聞辭貴之請。朕 } \\
\text { 方至公被物, 豈以小節從 } \\
\text { 人。宜增土宇, 更傳帶礪。 } \\
\text { 可加實封一千戶。 }{ }^{35}\end{array}$ & $\begin{array}{l}\text { (III) The turmoil has been settled; we hear only humble words } \\
\text { [from her]. The land of her estates has not been augmented; } \\
\text { We then receive her pleas, declining noble [rewards]. We, the } \\
\text { emperor, envelop everything with extreme impartiality. How } \\
\text { can We follow others in being constrained by the trivial } \\
\text { norms? It is appropriate that We endow additional territory } \\
\text { [to her]; let the land be hers until [the river lapses into] a belt } \\
\text { and [the mountains shrink into] a whetstone. It is approved } \\
\text { that she be supplemented with an additional thousand } \\
\text { households, as an actual source of income. }\end{array}$ \\
\hline
\end{tabular}

The edict, together with the reward, was a part of the complicated negotiation at the heart of the delicate alliance between Li Longji and Princess Taiping. ${ }^{36}$ On its surface, the throne was using this edict to reward Princess Taiping; in reality, Princess Taiping was one of the real powerholders behind the throne, and her agency permeated every part of the imperial decision making. Indeed, the edict acknowledged, in the emperor's voice, that Princess Taiping supported "Us" as the emperor. In other words, the edict publicly proclaimed a version of history that featured Princess Taiping as the agent who rescued the empire and pacified the realm.

\footnotetext{
${ }^{33}$ While the Secretariat 中書省 drafted an edict, it addressed the Chancellery 門下省, another leading bureau of the imperial bureaucracy, as audience. In theory the Chancellery was supposed to proofread it and sign it, and then pass the order down to the administrative branch of the government, the Department of State Affairs 尚書省, which, in the end, would issue another copy and endow the new income to Princess Taiping, the recipient of this reward. See Liu Houbin 劉後濱, Tangdai xuanguan zhengwu yanjiu 唐代選官政務研究 (Beijing: Shehui kexue wenxian chubanshe, 2016), 96.

${ }^{34}$ In this context, it refers to Gaozong and Wu Zhao.

${ }^{35}$ Song Minqiu 宋敏求, et al. comp., Tang da zhaoling ji 唐大詔令集 (Beijing: Shangwu yinshuguan, 1959), juan 42, 204.

${ }^{36}$ Unfortunately, the surviving sources do not reveal who drafted it.
} 
In fact, it is only in this edict that we hear this narrative so explicitly articulated, because the official histories, compiled after Li Longji's later triumph over Princess Taiping, present the event of 710 in a radically different tenor. In later accounts, $\mathrm{Li}$ Longji, the young prince and rightful heir to the throne, bravely led his followers in person, breaking into the palace and executing the "vicious" women who attempted to usurp power; what is more, such misogynistic historiography was eager to situate the 710 event as a part of Li Longji's larger project to eradicate female rule, a project that culminated in the execution of Princess Taiping in $713 .{ }^{37}$ Accordingly, the Jiu Tang shu biography, while downplaying Princess Taiping's role in the coups d'état in 705 and 710 , was highly critical of the power she had wielded. ${ }^{38}$ It stated that because "her power had eclipsed that of the sovereign ... and thus she was increasingly arrogant, [such that] her estates encompassed all fertile lands in the vicinity of the capital” (權移人主 ... 公主由是滋驕, 田園遍於近甸膏膄). ${ }^{39}$

While Jiu Tang shu utilized the trope of excessive luxury to delegitimize Princess Taiping's leadership, the 710 edict for her argues that given her supreme contributions, she deserved the very rewards that included the estates. The document itself attests to her power in constructing a narrative featuring her autonomous leadership and then incorporating this narrative into the imperial proclamation. Part (II) of the edict, one may also note, starts the eulogy with the imagery of flowers (hua 華, nongli liufang 穠李流芳). The floral tropes not only metaphorically stand for female beauty, but also metonymically refer to the virtues of male ministers, especially in accordance with the Chuci 楚辭 tradition. In addition, the flower of the plum (li 李) is a clever political pun, alluding to not only the blossom but also the ruling Li family. Thus, the language of flowers exuding their fragrance serves to foreground the femininity of Princess Taiping, but does so without subsuming her under a gender order with feminine attributes of yielding or gentleness. ${ }^{40}$ Indeed, when detailing her moral virtues and capacities, the edict deploys language that was traditionally associated with exemplary males. In other words, the use of floral metaphors and "male" virtues creates at an alternative rhetoric that weaves femininity and leadership together, a rhetorical strategy explored in more detail below.

At this point, it helps to compare the 623 imperial proclamations on Princess Pingyang with the 710 ones for Princess Taiping. The difference between the two concerns first and foremost the production and reception of each text. In the imperial speech of 623, because Princess Pinyang had already died, it was Emperor Gaozu (and his secretariat) that honored this heroine, while glorifying the Li family's founding of the Tang. In the case of the edict of 710, Princess Taiping, while being the recipient of the document, was also one of the powerholders behind its production. What is more, Princess Pingyang's biography in Jiu Tang shu ultimately incorporated the very speech of Emperor Gaozong. In contrast, in her biography in Jiu Tang shu, Princess Taiping is portrayed as becoming increasingly corrupt from at least 705 to

\footnotetext{
${ }^{37}$ Liu Xu et al., Jiu Tang shu, juan 8, 168.

${ }^{38}$ Liu Xu et al., Jiu Tang shu, juan 183, 4739. According to this biography, Princess Taiping only "participated in" ( $y u$ 預) the coups d'état. For how post-Tang sources delegitimize women's leadership, see Doran, Transgressive Typologies.

${ }^{39}$ Liu Xu et al., Jiu Tang shu, juan 183, 4739.

${ }^{40}$ In fact, the edict did not opt to eulogize Princess Taiping in terms of feminine virtues such as softness and submissiveness (rou 柔 and shun 順), as a previous one in 705 did, which also endowed her with additional households of income. See Song Minqiu, comp., Tang da zhaoling ji, juan 42, 204.
} 
her death in $713 .{ }^{41}$ The edict of 710 thus offers unique access to how the court, under the influence of her power, described her achievements.

By modern standards, Princess Pingyang might better represent a typical female commander than Princess Taiping, but the Tang rhetoricians eulogized them using a similar rhetorical repertoire featuring the brilliance of princesses. Neither text depicts the heroine as a mere leader of troops, and both emphasized that the women were critical to the pacification of the entire realm. What is more, both edicts strongly emphasized the exceptional nature of the princesses. If the imperial speech of 623 authorized the use of the fife and drum band for Princess Pingyang on the grounds that she was an extraordinary woman who deserved this honor previously monopolized by men, the 710 edict for Princess Taiping further advanced the claim that a female might "greatly transcend" all her peers, both male and female. Accordingly, while both edicts attest to the independent agency of the princesses, they present them as exceptional cases, not subject to normative gender expectation.

\section{Balancing Female Virtues and Army Commanderships}

Not all women of military valor attained the honor of a biography in the dynastic histories, but we can sometimes glimpse them in other surviving documents. At least since 883, one Ms. Liu 劉氏 had been commanding troops and attacking fortifications; together with her husband Xu Qing 許就, the Prefect of Chúzhou in Huainan, she helped to consolidate their gains in this prefecture. ${ }^{42}$ Meanwhile, in 887, when Zheng Hanzhang 鄭漢章 was attacking Yangzhou, Huainan's provincial seat, his wife (whose name is not preserved in extant records) was defending the key garrison of Huaikou, frustrating the besiegers for dozens of days until her husband's side triumphed and broke the siege. ${ }^{43}$ The two scenarios are revealing of the emerging military and political situation of the 880s. While the imperial court and even the provincial authorities were losing control over prefectures, individuals-and married coupleswith their own bands of soldiers became important powerholders. ${ }^{44}$ Autonomously controlled fortifications pointed to new patterns of domination. ${ }^{45}$

This section proposes that official documents endowing titles and rewards to women offer unique access to the micro-mechanisms of power. As we shall see, on the one hand, these female commanders played an important role through the patrimonialization of power during which rising magnate families competed to appropriate governmental offices and territorial jurisdiction as an inheritable asset within the family. On the other hand, provincial governors, having seized the authority to issue edicts on behalf of the imperial court, sought to communicate with these female commanders, conferring titles on them with the hope of gaining their support. Ch'oe Ch'i-wŏn, the Silla-born belletrist working at the provincial court, demonstrated his rhetorical virtuosity in weaving women's marital and martial roles together.

\footnotetext{
${ }^{41} \mathrm{Liu} \mathrm{Xu}$ et al., Jiu Tang shu, juan 183, 4738. For an interesting analysis of the "imperial relationship to nature," see Doran, Transgressive Typologies, 108.

${ }^{42}$ Ch'oe Ch'i-wŏn (Cui Zhiyuan) 崔致遠, Gui yuan bi geng ji jiao zhu 桂苑筆耕集校註, ed. Dang Yinping 黨銀平 (Beijing: Zhonghua shuju, 2008) [hereafter GWPG], juan 12, 363.

${ }^{43}$ Sima Guang et al., ZZTJ, juan 257, 8471.

${ }^{44}$ Nicolas Tackett, The Destruction of the Medieval Chinese Aristocracy (Cambridge, MA: Harvard University Asia Center, 2014), esp. 187-234.

${ }^{45}$ For the general trends in the development of fortifications, see Otagi Hajime’s 愛宕元 chart in Tōdai chiiki shakaishi kenkyū 唐代地域社会史研究 (Kyōto: Dōhōsha, 1997), 455-88.
} 


\section{Re-Writing the Female "General" in the Late Tang}

To understand female commandership in late Tang Huainan, it is helpful to start with a general background of the Tang after the An Lushan Rebellion (755-763). While historians have noted that provinces had gained increasing importance during the eighth and the ninth centuries, recent scholarship has shown that this does not mean the empire was in inevitable decline. ${ }^{46}$ As Nicolas Tackett has notably argued, the Tang had successfully adapted itself to the new situation during most of the ninth century. ${ }^{47}$ It suddenly collapsed in the 880s, only after the Huang Chao Rebellion (874-884) led to massacres of the capital's population and the physical annihilation of the aristocracy that constituted the political backbone of the empire.

Huang Chao was able to break into the Tang capital region in 880 precisely because he could penetrate the Tang defensive lines in and around Huainan, the region of our current focus. No later than 880 , the provincial governor Gao Pian 高駢 $(821-887)^{48}$ employed Ch'oe Ch'i-wŏn to draft documents in his name. Before going back to Silla in 884 , Ch'oe crafted a variety of administrative documents on behalf of Gao, many of which have survived in Ch'oe's collected works. Thus, his collection is particularly valuable in revealing how the Tang provincial government functioned during the years when the rebels crossed this very area and destroyed the empire.

It informs us, among other things, that most likely in late 883 but no later than early 884, Gao was communicating with Xu Qing, the Prefect of Chúzhou, concerning Xu's wife who had volunteered to join the battle. The timing is important, because in 883 Gao lost control over a number of his subordinate prefectures. ${ }^{49}$ Though he appointed his trusted generals to the prefectures of Hezhou and Luzhou, in both cases his appointees were expelled by magnates who had their own troops in the respective locales, and Gao could do nothing but recognize the rising magnates as the legitimate prefects, hoping to establish an alliance with them. ${ }^{50}$ As Hezhou and Luzhou together formed a bridge to the western half of the province, Gao's influence was thereafter confined to prefectures adjacent to the provincial capital of Yangzhou.

Chúzhou, where Ms. Liu and Xu Qing were based, was one of the three prefectures contiguous with Yangzhou. Both of peasant origin, Ms. Liu and Xu Qing had joined

\footnotetext{
${ }^{46}$ For recent revisionist accounts in Chinese, see Li Biyan 李碧妍, Weiji yu chonggou 危機與重構 (Beijing: Beijing shifan daxue, 2015); Qiu Luming 仇鹿鳴, Chang'an yu Hebei zhijian 長安與河北之間 (Beijing: Beijing shifan daxue, 2018).

${ }^{47}$ Tackett, The Destruction of the Medieval Chinese Aristocracy, 146-86.

${ }^{48}$ While dynastic histories since the tenth century have contended that Gao Pian hid to avoid confronting the rebels, recent scholarship offers a more nuanced picture according to which Gao's military strength was itself constrained. See Sudō Yoshiyuki 周藤吉之, Sō, Kōrai seidoshi kenkyū 宋・高麗制度史研究 (Tōkyō: Kyūko shoin, 1992), 521-52; Chen Zhijian 陳志堅, “Tangmo Zhonghe nianjian Xu Si Yang bingzheng zhi shimo” 唐末中和年間徐泗揚兵爭之始末, Ludong daxue xuebao 魯東大學學報 5 (2008), 20-25.

${ }^{49}$ Gao's regime collapsed in 887. For a revisionist account of Gao Pian's downfall, see Shangen Zhisheng (Yamane Naoki) 山根直生, “Tang chao junzheng tongzhi de zhongjie yu wudai shiguo geju de kaiduan” 唐朝軍政統治的終局與五代十國格局的開端, Zhejiang daxue xuebao 浙江大學學報 34:3 (2004), 71-80. In this meticulous study, Yamane shows that Gao's downfall was rooted in his financial difficulties, instead of his adherence to alchemy or other sinister practices, as dynastic histories have stressed. Here I show that Gao's financial difficulties resulted from his inability to exert control over Huainan's key prefectures.

${ }^{50}$ See Guangling yaoluan zhi 廣陵妖亂志, in Luo Yin ji 羅隱集, edited by Yong Wenhua 雍文華 (Beijing: Zhonghua shuju, 1983), 245; Sima Guang et al., ZZTJ, juan 253, 8338.
} 
rebel forces no later than 878 , and during previous years, they had been fighting together. Having defected to Gao in the first month of $879,{ }^{51}$ the couple brought their own troops to Chúzhou around 883, whereupon Xu Qing was granted the title of prefect by Gao. Gao, for his part, hoped to maintain his dominion, and $\mathrm{Xu}$ also knew it was to his advantage to maintain a friendly relationship with Gao. It is against this background that $\mathrm{Xu}$ memorialized Gao, pleading for official recognition for his wife. This in turn gave Gao an opportunity to extend his influence over Chúzhou through diplomatic means. By this point, the events in Hezhou and Luzhou had taught him that it was hardly possible, if desirable at all, to subjugate these prefectures militarily. Though the original letter from Xu Qing does not survive, Gao's reply, drafted by Ch'oe Ch'i-wŏn and translated below, offers a glimpse of the complicated relationship between Gao and his prefect Xu:

\begin{tabular}{|c|c|}
\hline 委曲 : 滁州許勍 & $\begin{array}{l}\text { Directive: to Xu Qing, [the prefect of] Chúzhou } \\
\text { (883 or early } 884 \text { ) }\end{array}$ \\
\hline 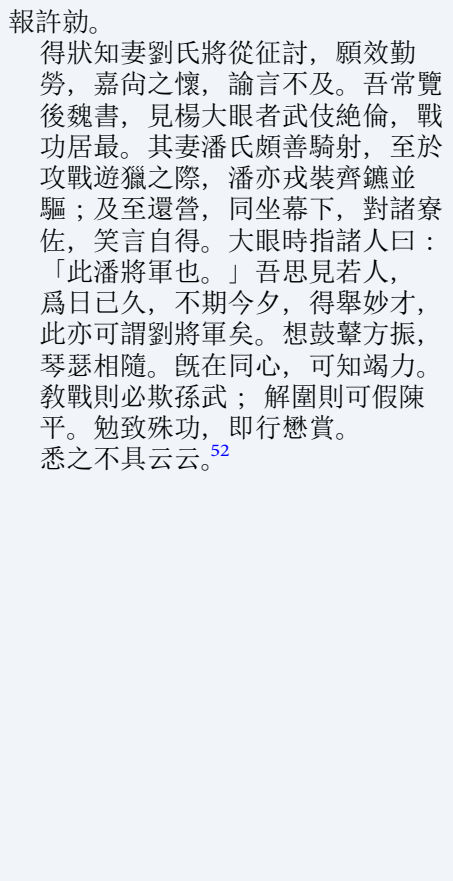 & $\begin{array}{l}\text { Reply to Xu Qing. } \\
\text { I have received your memorial, which informs me that } \\
\text { your wife Ms. Liu will follow you in campaign and that } \\
\text { she is willing to offer her service. My appreciation [of } \\
\text { her] is beyond words. Reading the History of the Later } \\
\text { Wei, I have noticed that a certain Yang Dayan had } \\
\text { exceptional fighting skills, and his achievement in war } \\
\text { ranked first. His wife Ms. Pan quite excelled at } \\
\text { mounted archery, so that in times of battle or when } \\
\text { hunting, Pan also dressed herself in military clothing, } \\
\text { charging on horseback together [with her husband]. } \\
\text { When they returned to the camp, she sat under the } \\
\text { tent together [with Yang Dayan], facing their } \\
\text { subordinates. She conversed and laughed with them, } \\
\text { enjoying herself. At the time, Dayan pointed to those } \\
\text { present and said: "This is General Pan." Long I have } \\
\text { yearned to see a person like her, and I did not expect } \\
\text { that today you would recommend such a wonderful } \\
\text { talent to me. This person can be called General Liu. I } \\
\text { imagine that when the drums of gu and pi begin the } \\
\text { campaign, the instruments of qin and se follow each } \\
\text { other as a couple. }{ }^{53} \text { As you [two] share the same heart, } \\
\text { I know you will make the utmost effort. In training } \\
\text { armies, you will definitely surpass Sun Wu; in } \\
\text { breaking a siege you will be like Chen Ping. }{ }^{55} \text { Endeavor } \\
\text { to pursue exceptional achievements and I will then } \\
\text { issue a great reward. I shall not delve into further } \\
\text { details here. }\end{array}$ \\
\hline
\end{tabular}

${ }^{51}$ Sima Guang et al., ZZTJ, juan 253, 8332.

${ }^{52}$ Ch'oe Ch'i-wŏn, GWPG, juan 12, 363.

${ }^{53} \mathrm{Qin}$ and se are two string instruments that are often played together. See Sima Qian 司馬遷, Shi ji 史記 (Beijing: Zhonghua shuju, 1982), juan 24, 1211.

${ }^{54}$ On Sun Wu, see Daniels, "Killing the King's Concubines."

${ }^{55}$ Thanks to Chen Ping's (? -178 BCE) strategies, Liu Bang (256 -195BC) was able to break the sieges of Xiongnu. See Sima Qian, Shi ji, juan 56, 2057. 
This document, categorized as weiqu 委曲, which I translate as a “directive," is the kind of official document by which mid- and late Tang provincial authorities could communicate with their subordinates in a highly informal manner. ${ }^{56}$ The order was released under Gao's own name; however, as a practice of the times, Ch'oe was responsible for crafting the text, and it is for this reason that it survives in Ch'oe's collected works. The making of such official documents, as Robert Ashmore has illustrated, was premised upon a collaborative process between the governor and the documentdrafting official. ${ }^{57}$

A substantial part of the text centers upon Wei shu's account of Ms. Pan, Yang Dayan's wife. Raising this historical precedent of female commandership, Ch'oe adroitly fulfilled the main task of this document, that is, to promise future rewards to Ms. Liu if she would side with the provincial authorities in the future. While Ch'oe recounts a scene from Wei $s h u$, his rewriting of the story is subtle yet significant:

\begin{tabular}{|c|c|}
\hline $\begin{array}{l}\text { Excerpt on Ms. Pan, Wei shu, or History of the } \\
\text { Wei (completed in } 555)^{58}\end{array}$ & $\begin{array}{l}\text { The corresponding line in Ch'oe's “Order: to Xu } \\
\text { Qing” }\end{array}$ \\
\hline $\begin{array}{l}\text { In times of battle or when hunting, Dayan } \\
\text { ordered his wife Ms. Pan to dress in military } \\
\text { clothing; together they charged on horseback } \\
\text { onto the battlefield or galloped in mountains } \\
\text { and valleys. }\end{array}$ & $\begin{array}{l}\text { In times of battle or when hunting, Pan also } \\
\text { dressed herself in military clothing, charging } \\
\text { on horseback together [with her husband]. }\end{array}$ \\
\hline $\begin{array}{l}\text { 至於攻陳遊獵之際, 大眼令妻潘戎裝, 或齊 } \\
\text { 鏕戰場, 或並驅林壑。 }\end{array}$ & 至於攻戰遊獵之際, 潘亦戎裝齊鏕並驅。 \\
\hline
\end{tabular}

The account in Wei shu explicitly emphasizes that Yang ordered his wife to join him in battle and in hunting. In Ch'oe's account, however, Ms. Pan became the grammatical subject of the sentences and she, on her own initiative, put on military attire and then entered onto the battlefield. In this way, Ch'oe deliberately rejects the Wei shu approach of portraying Ms. Pan as a passive follower of her husband's orders. Instead, Ch'oe brings Pan to the foreground, exploring an alternative approach to writing about female commanders: it is not the wife who assists the husband to achieve his goals, but the couple-composed of two autonomous individuals, that is, the wife and the husband-who together pursue the goals that they share. However, this does not mean that Ch'oe treated husband and wife as equals or peers. Ch'oe would conceptualize their relationship in a more complex way, as seen below.

\section{Balancing Marital and Martial}

As Gao fulfilled his promise of bestowing a title on Ms. Liu, Ch'oe was commissioned to compose the relevant edict. The title of the document in the received collection —“Conferring the Title of Lady of Pengcheng Prefecture on Xu Qing's Wife” (許就 妻劉氏封彭城郡君)一makes it explicit that it belongs to the genre of “edict bestowing

\footnotetext{
${ }^{56}$ See Lin Song 林嵩, “Guiyuan bigeng ji suojian weiqu tan ze” 桂苑筆耕集所見委曲探賾, Zhongguo dianji yu wenhua 中國典籍與文化 73 (2010), 38-43.

${ }^{57}$ See Robert Ashmore, "The Mastering Voice: Text and Aurality in the Ninth-century Mediascape," in Memory in Medieval China: Text, Ritual, and Community, edited by Wendy Swartz and Robert F. Campany (Leiden: Brill, 2018), 245.

${ }^{58}$ Wei Shou, Wei shu, juan 73, 1634.
} 
a noble title on a woman outside [the palace] (wai mingfu 外命婦).” Under normal circumstances, it was the imperial court that issued such edicts. In the early 880 s, because Huang Chao was occupying the capital, the court found itself in exile in Chengdu. It had no choice but to delegate to Gao (and certain other governors) the imperial prerogative of issuing edicts of expediency (mochi 墨敕) on behalf of the throne-a privilege that the court would find hard to revoke in subsequent years. As Gao seized the imperial authority of issuing the mochi edict, Ch'oe was thus entrusted with the responsibility of crafting edicts that, under normal circumstances, only the imperial court could issue. $^{59}$ Thus, while parts (I) to (III) of the following document follow the tri-partite structure of an imperial edict, the document incorporates a fourth part, acknowledging its expedient nature and anticipating that an imperial envoy (the "phoenix") would bring a further document to fully validate the appointment.

\begin{tabular}{|c|c|}
\hline 許勍妻劉氏封彭城郡君 & $\begin{array}{l}\text { Conferring the Title of Lady of Pengcheng Prefecture on } \\
\text { Xu Qing's Wife }\end{array}$ \\
\hline 牒：奉處分。 & Notification: following command. \\
\hline $\begin{array}{l}\text { 古者官至大夫。室稱命婦。遂有從夫 } \\
\text { 之貴。乃爲處世之榮。而況靜則能 } \\
\text { 愼內言。動則克從外役。躬擐甲 } \\
\text { 甹。志凌雪霜。功名朁異於常流。 } \\
\text { 封拜豈拘於成命。 }\end{array}$ & $\begin{array}{l}\text { (I) In antiquity, when an official reached the rank of } \\
\text { Grand Master, his wife would be referred to as a lady } \\
\text { with an endowed title. Thus, a woman follows in her } \\
\text { husband's ascent to nobility, which is the glory that } \\
\text { follows from being engaged in the world. Not to } \\
\text { mention that in tranquility, [this woman] shows the } \\
\text { prudence of the language of the inner quarters; in } \\
\text { action, she devotes herself to campaigns in the outer } \\
\text { domain. }{ }^{60} \text { She wears armor, and her aspiration is [as } \\
\text { pure and noble] as snow and frost. For such a person } \\
\text { whose contribution differs from the common ones, } \\
\text { how can the conferring of titles be constrained by the } \\
\text { common standard? }\end{array}$ \\
\hline $\begin{array}{l}\text { 以滁州刺史許就妻劉氏 : 英才天授, } \\
\text { 貞節日彰。平欺後魏將軍, 洛陽失 } \\
\text { 行 ; 仰慕聖朝公主, 司竹興兵。一 } \\
\text { 昨專命良夫, 討除叛卒, 遽陳丹 } \\
\text { 赤, 固願同征。手驅組練之群, 遠 } \\
\text { 攻城壘; 身脫綺羅之色, 久犯氛 } \\
\text { 埃。四德有餘, 六鞱可試, 豈獨家 } \\
\text { 之肥也, 實謂邦之媛兮。 }\end{array}$ & $\begin{array}{l}\text { (II) Regarding Ms. Liu, wife of Xu Qing, the Prefect of } \\
\text { Chúzhou: from heaven, she receives her brilliant } \\
\text { talents; day after day, her principled chastity becomes } \\
\text { more illustrious. Clearly, she surpasses the general } \\
\text { [Pan] of the Later Wei, who in Luoyang lost her } \\
\text { integrity; humbly, she emulates the Princess [of } \\
\text { Pingyang] of our sagely dynasty, who in Sizhu raised } \\
\text { her army. Previously, we appointed the righteous man } \\
\text { [that is, Xu Qing] to clear the bandits, whereupon she } \\
\text { firmly resolved to join the campaign. Her hand } \\
\text { commanded the troops, which were grouped and } \\
\text { trained, attacking the fortification from afar; her body } \\
\text { declined the luster of the colored and soft [silk], long } \\
\text { confronting the dust [of the battlefield]. }\end{array}$ \\
\hline
\end{tabular}

\footnotetext{
${ }^{59}$ On the category of mochi 墨敕 that Ch'oe brushed, see You Ziyong 游自勇, “Mozhao mochi yu Tang Wudai de zhengwu yunxing” 墨詔墨敕與唐五代的政務運行, Lishi yanjiu 歷史研究 (2005), 32-46.

${ }^{60}$ The parallel of jing 靜 and dong 動 re-appropriates the rhetorical structure of the phrase “in the beginning [tranquil] as unmarried woman, ... later [agile] as escaping rabbit” 始如處女後如脫兔, which Sima Qian used to appraise Tian Dan's talent in deploying troops (Sima Qian, Shi ji, juan 82, 2453). While "unmarried woman" in the original phrase alluded to female virtues within the inner quarter, the imagery of running rabbits point to the last couplet of Mulan shi, where the male and female rabbits are no longer distinguishable (Guo Maoqian ed., Yuefu shiji, juan 25, 374). I thank the anonymous reviewer for pointing this out.
} 
[Exemplifying] the four virtues [of women], ${ }^{61}$ she still has the energy to spare, and thus she has explored the six strategies [of warfare]. Not only a treasure to the household, ${ }^{62}$ she is also a lady of the realm $!^{63}$

夫朁冠其銀鐺, 婦宜榮於石窌。豈可 使松標峻影, 早致凌雲; 蘿抱柔 姿, 猶嗟委地。先行茂賞, 用報前功。
(III) The husband has been promoted with a silver attachment to his hat; the wife should be honored in the place of Shiliu. ${ }^{64}$ How can it be that, while the pine that reaches the cloud early on has been recognized by its handsome shadow, the vines with her gentle disposition are still abandoned on the ground? Here, we issue the distinguished award, to reward her previous contribution.
軍中之命爵策勳, 與人從欲。天上之 錦茂鈿軸, 待鳳銜來。事須准詔, 行墨勑封彭城郡君，仍表次錄奏。 竝牒知者。6
(IV) To endow titles of nobility and to record meritorious service in the army is to accord with expedient needs. As for the silken scrolls from Heaven, one waits for the phoenix to bring it here. The issue at hand should follow the imperial proclamation. Here, [we] exercise the order on behalf of the throne, endowing the title of Lady of Pengcheng Prefecture. We memorialize the throne while issuing the order.

In the previous weiqu directive, Gao, via the brush of Ch'oe, left Ms. Liu with the impression that she would earn rewards if she achieved military success. Here, Gao seems to fulfill that promise, but it is a mere gesture. Gao endowed her with the rank that she should have obtained by default, given her husband's position. As the order itself acknowledges, "since antiquity," a wife of an accomplished official, as a dependent of her husband, received her own title of nobility. By then, Xu Qing's official position as Prefect of Chúzhou gave him the rank of Upper $4 \mathrm{~b}$; and according to the Tang institutional code, his wife should have received the title of Lady of such-and-such Prefecture, which, indeed, was what she was granted via the above order. ${ }^{66}$ In other words, Gao did not really confer more honors upon Ms. Liu than she should have already received.

Crafting this mochi or edict of expediency posed a challenge for Ch'oe. On the one hand, unlike the informal communication (weiqu), the genre of wai-mingfu 外命婦 edicts had its own formula. It was imperative to eulogize the recipient in terms of

\footnotetext{
${ }^{61}$ According to Ban Zhao’s 班昭 “Admonitions for Women” (Nü jie 女誡), “a woman ought to have four qualifications (si xing 四行): womanly virtue, womanly words, womanly bearing, and womanly work.” See Fan Ye, Hou Han shu, juan 84, 2784.

${ }^{62}$ This alludes to the following line in Liji 禮記: “Harmony between husband and wife is the treasure of the family”夫婦和，家之肥也. See Sun Xidan 孫希旦, Liji ji jie 禮記集解 (Beijing: Zhonghua shuju, 1989), juan 22, 620. While alluding to this line of spousal harmony, Ch'oe retailored it to feature Ms. Liu as the treasure. This showcases Ch'oe's art in weaving the wife's role in the exemplary marital relationship and her valor in the martial context.

${ }^{63} \mathrm{Ma}$ Ruichen 馬瑞辰, Maoshi zhuanjian tong shi 毛詩傳箋通釋 (Beijing: Zhonghua shuju, 1989), 178.

${ }^{64}$ This refers to an episode in 589 BCE when the Prince of Qi granted a settlement to a woman because she ran away from danger only after confirming that her ruler and father had escaped. See Stephen Durant et al., Zuo Tradition/Zuozhuan, 720.

${ }^{65}$ Ch'oe Ch'i-wŏn, GWPG, juan 12, 363.

${ }^{66}$ See Wu Chia-jung 吳佳蓉, “Tangdai waimingfu de shenfen yu juefeng” 唐代外命婦的身份與爵封 (MA diss., Feng Chia University, 2009).
} 
feminine virtues prescribed by normative texts, among which gentleness and a yielding disposition were some of the default attributes. On the other hand, it was supposed to convey the message that the court was justly rewarding Ms. Liu's military achievements. In fact, what really distinguishes the current document from the edicts of the wai-mingfu tradition is that Ch'oe's piece states without ambiguity that Ms. Liu earned her title, not only as a result of her husband's official rank, but also as an award (shang 賞) to "reward her previous contribution." In brief, while the genre of wai-mingfu dictated that he should portray Ms. Liu as an exemplary wife, the real situation in Huainan required Ch'oe to eulogize Ms. Liu in a way that acknowledged her military valor.

Ch'oe did not shy away from this challenge. ${ }^{67}$ Instead, he evoked the transcendent strategy-a strategy that we have encountered in the edicts for Princesses Pingyang and Taiping - at the very beginning, stating that Ms. Liu differed from commoners. However, he then embarked upon an alternative model, reframing the relationship between women's marital and martial roles. At first glance, the rhetorical crux lies in his allusion to Confucius's authoritative instructions with regard to the cultivation of virtue (in the case of noble men) and the study of wen 文 (literature). According to the Lunyu 論語 (Analects) 1.6:

The Master said: "At home, a young man must respect his parents; abroad, he must respect his elders. He should talk little, but with good faith; love all people, but associate with the virtuous. Having done this, if he still has energy to spare, let him study literature." 68

For Confucius, his disciple should exemplify the five virtues first; and then, if he still has "energy to spare," he should move on to study wen 文, meaning literate learning in a broad sense. Ch'oe applies the same rhetorical structure to Ms. Liu: as she already exemplified the four virtues that early normative texts ascribed to women, her remaining energy allowed her to step into the field of army commandership, just as virtuous men with remaining energy might delve into literary learning.

However, Ch'oe was not composing a philosophical exegesis. The rhetoric of government documents was supposed to proceed through pairs of parallel lines, where a four-six meter was required. Ch'oe's literary mastery gave him the tools to turn this formulaic parallelism into a literary vehicle for reconciling the tensions between femininity and war leadership. To give an example, Ch'oe used zulian 組練 (literally, grouping and training) to describe Ms. Liu's leadership of troops, paralleling it with qiluo 綺羅 (splendid silk, commonly associated with female beauty). The same radical of $s i$ 糸 (literally, silk or fine thread), shared by both pairs of characters, diminishes the sharpness of the contrast between martiality and femininity, thereby helping to bridge two otherwise opposing imageries.

\footnotetext{
${ }^{67}$ Ch'oe was not the first of the Tang rhetorician ministers who composed an edict promoting women who fought in war. During Wu Zhao's reign, the court had already issued an edict conferring the title of County Lady of Following Loyalty (徇忠縣君) to Gu Xuanying's wife, the key line of which reads: “When the man [the husband] was resolutely defending [the city] but still could not hold the line, the woman [the wife], because of her loyalty, was not afraid of the flying arrows. Thus, [the defenders] were motivated, and the jeopardized city was safe again.” (丈夫固守, 猶不能堅 ; 婦人懷忠, 不憚流矢。由茲感激, 危城 重安). See Jiu Tang shu, juan 150, 5146). Though the edict was issued to promote the female protagonist, the version that Jiu Tang shu cites (or abbreviates) minimizes her agency. For the political background, see N. Harry Rothschild, Wu Zhao: China's Only Female Emperor (London: Pearson, 2007), 175.

${ }^{68}$ Michael Nylan, ed. The Analects of Confucius: A Norton Critical Edition (New York: W. W. Norton, 2014), 3.
} 
In this manner, Ch'oe builds a narrative in which both the husband and the wife were commanders in their own right, though the latter was still inferior to the former. In part (III), for instance, the edict specifies that both the husband and the wife deserved rewards for their deeds, though the husband stands before his wife as pine before grass. Ch'oe carefully distances himself from depicting the female commander as a mere dependent of her campaigning husband, even while he maintains a gender hierarchy that places the husband above the wife. In short, while concrete political negotiations in Huainan around 883 facilitated an alternative articulation of femininity and military commandership, it was Ch'oe's literary mastery that wove the two themes together.

Ms. Liu was not the only woman who led troops independently while pursuing a military campaign together with her husband. As mentioned above, Zheng Hanzhang's wife was simultaneously leading troops in Huaikou. The eleventh-century chronicle Zizhi tongjian 資治通鑑 (The Comprehensive Mirror for Governance), synthesizing multiple tenth-century accounts, explains that Zheng Hanzhang "left his wife behind to defend Huaikou." (留其妻守淮口). ${ }^{69}$ Here, as in the dynastic history biographies, what actually happened was retroactively sanitized by means of the reductionist approach. In the absence of documents such as those that survive for Ms. Liu, we can know little about the leadership of Zheng's wife.

The rise of female commanders in this region as observed in these documents attests to a broader historical trajectory whereby military leadership was increasingly premised upon personal ties later formalized by official positions conferred from above. It is probably safe to assume that, like other, more successful magnates in the region, $\mathrm{Xu}$ Qing and Ms. Liu hoped to turn the troops as well as government office into an inheritable asset that they could pass down to their descendants. ${ }^{70}$ The major obstacle that they faced was not only that the provincial government sought to avoid acquiescing to their de facto autonomous status marked by the hereditary transition of the position of the prefect. It was also that many of their followers were themselves leaders of personal armies; if the situation allowed, they would themselves seize a territorial unit, be it a garrison town or a county seat. The increasing prevalence of small family dynasties of this sort meant that Ms. Liu was an especially reliable partner for Xu Qing.

\section{Women and Warfare Beyond Medieval China: Concluding Remarks}

Overall, this article has identified three distinct strategies of writing about female commanders. In conclusion, we can ask how the rhetorical differences outlined in the previous sections shed new light upon deeper patterns of gender and power in Chinese history. Put differently, how shall we understand the phenomenon of the court or its regional administration deploying approaches different from the "reductionist" one? Given that the evidence for the "transcendent" and "eclectic" strategies are taken from Tang sources, one may wonder if these two approaches were innovations of that dynasty. For example, perhaps a Sino-Steppe culture inherited by the Tang founders made it possible for Tang authors to write about women of power in different ways-a possibility that

\footnotetext{
${ }^{69}$ ZZTJ, juan 253, 8338.

${ }^{70}$ Unfortunately, Ms. Liu and her husband would fail and would soon disappear from the received record. But at least four magnates in Huainan, who rose to prominence in the $880 \mathrm{~s}$, succeeded in passing their prefecture to their heirs. They include (1) Yang Xingmi 楊行密 in Yangzhou, the provincial capital (Yang and his heirs were also the provincial governor of Huainan before they proclaimed themselves King of Wu); (2) Liu Jin 劉金 and his descendants in Haozhou, for three generations; (3) Zhou Ben 周本 and his descendants in Luzhou; (4) Jiang Yanwen 江彥溫 and his descendants in Shouzhou. See Yu Xianhao 郁賢皓, Tang cishi kao quanbian 唐刺史考全編 (Hefei: Anhui daxue, 2000), 1655-844.
} 
other scholars have explored. ${ }^{71}$ But it is important to remember that relatively fewer documents representing imperial speech survive from pre-Tang times.

Against this backdrop, I would like to suggest another alternative, especially in light of the Huainan examples, where we are dealing not with an author seeped in Sino-Steppe interactions, but rather with a rhetorician-minister with roots in the Sino-Korean classical tradition. I contend that, in the context of the concrete political need to engage with and respond to female commanders, medieval Chinese courts deployed different approaches to eulogize them despite their transgression of perceived gender norms.

Here it is significant that the sources I have investigated are edicts and other official documents. I obtained these previously under-utilized sources both through a survey of collections (including those surviving outside of China) and also through a critical reading of dynastic history narratives. If biographical narratives of a retrospective nature can be seen as "a negotiation between what actually happened and what can be found in the discursive tradition," as Rebecca Doran nicely puts it, edicts and other official documents were further shaped by specific political needs of the court that issued them. ${ }^{72}$ Emperor Gaozu, through eulogizing the deceased Princess Pingyang, sought to reassert the legitimacy of his dynasty-an issue of grave concern a mere five years after the dynasty's founding. By rewarding Princess Taiping, the court (under her influence) re-confirmed her claim to political power in the context of the delicate alliance among different powerholders. And by re-framing the marital and martial virtues of Ms. Liu, Gao Pian (via the hands of Ch'oe) sought to gain her (and her husband's) loyalty. In all these cases, the recognition of women's achievements was conditioned not only by deep cultural/literary tradition(s) but also by immediate political/military goals of the regime. The implication, accordingly, is that it will be productive to bring gender studies and official document studies into closer dialogue with each other. Further examinations of descriptions of women in all kinds of functional documents will likely lead to a more dynamic picture of how patriarchal regimes actually functioned in premodern China, and perhaps beyond. ${ }^{73}$

\footnotetext{
${ }^{71}$ This view may date back to Chen Yinke 陳寅恪, Tangdai zhengzhi shi shulun gao 唐代政治史述論稿 (Shanghai: Shanghai guji, 1997), esp. 1-49.

${ }^{72}$ Doran, Transgressive Typologies, 33.

${ }^{73}$ To give just one example, the edict appointing Shang Sheng, wife of Fa Shu, Prefect of Wuding Military and Civilian Command, survives in the Yunnan jiwu chao huang 雲南機務抄黄 (Copies of key documents concerning Yunnan from the Imperial Archives) - a collection that has been barely tapped in modern scholarship. Issued in 1383, a central part of the document stated: "For Shang Sheng, wife of Fa Shu, the previous tribal official of Wuding Command, while her disposition is gentle and yielding, her intention values strength and chastity/integrity. She submits from ten thousand li away. This is indeed laudable." 前 武定府土官法叔妻商勝, 質雖柔淑, 志尚剛貞, 萬里來歸, 誠可嘉賞. See Zhang Dan 張統, Yunnan jiwu chao huang 雲南機務抄黃 (Jinan: Qilu shushe, 1996), 275a. It is helpful to recall that medieval rhetorical practices did not require men like Ch'oe to analyze philosophically the appointee's moral disposition. One did not need to resolve an obvious paradox: If the wife has to be gentle and yielding, how can she lead troops and attack fortifications? This edict of 1383 argues that the qualities of both yielding (rou 柔) and unyielding (gang 剛) co-exist in the same person at different levels-the former belongs to the disposition by which one is physically composed ( $z h i$ 質), while the latter belongs to the realm of intention that one forms through one's own will (zhi 志). It seems that the early Ming drafter deployed rhetorical approaches that were both indebted to and different from the medieval counterparts examined above.
} 


\section{Appendix: List of Cited and Mentioned Edicts}

\begin{tabular}{|c|c|c|}
\hline Date & Title & Source \\
\hline 623 & $\begin{array}{l}\text { [Imperial Speech Authorizing the Use of Fife } \\
\text { and drum in the Burial Ceremony of Princess } \\
\text { Pingyang] }\end{array}$ & Jiu Tang shu, juan 58, 2316. \\
\hline ca. 697 & $\begin{array}{l}\text { Edict Conferring the Title of County Lady of } \\
\text { Following Loyalty to Gu Xuanying's Wife } \\
\text { 封古玄應妻為徇忠縣君詔 }\end{array}$ & Jiu Tang shu, juan 150, 5146. \\
\hline 705 & $\begin{array}{l}\text { Edict Endowing Additional Actual Households } \\
\text { of Income to the Princess of the Great Peace } \\
\text { [that is, Princess Taiping] 加太平公主實封制 }\end{array}$ & Tang da zhaoling ji, juan 42, 204. \\
\hline 708 & $\begin{array}{l}\text { Edict Authorizing the Use of Fife and drum on } \\
\text { the Burial Day of Imperial Concubines and } \\
\text { Princesses 許妃主等葬日給鼓吹制 }\end{array}$ & $\begin{array}{l}\text { Excerpt in Jiu Tang shu, juan } 85 \text {, } \\
2813 .\end{array}$ \\
\hline 710 & $\begin{array}{l}\text { Edict Endowing Additional Actual Households } \\
\text { of Income to the Princess Guardian of the } \\
\text { Realm and of the Great Peace [that is, } \\
\text { Princess Taiping] 鎮國太平公主加實封制 }\end{array}$ & Tang da zhaoling ji, juan 42, 204. \\
\hline 710 & $\begin{array}{l}\text { Edict [Confirming that] Princess of the Great } \\
\text { Peace Continues Opening Office 太平公主依 } \\
\text { 舊置府敕 }\end{array}$ & Excerpt in Tang huiyao, juan 6, 72 \\
\hline ca. 883 & $\begin{array}{l}\text { Directive: to Xu Qing, [the prefect of] Chúzhou } \\
\text { 委曲 : 滁州許勍 }\end{array}$ & GWPG, juan 12, 363. \\
\hline ca. 883 & $\begin{array}{l}\text { [Edit of expediency] Conferring the Title of Lady } \\
\text { of Pengcheng Prefecture to Xu Qing's Wife } \\
\text { 許就妻劉氏封彭城郡答楊行省書君 }\end{array}$ & GWPG, juan 12, 363. \\
\hline 1129 & $\begin{array}{l}\text { [Edict Conferring the Title of Realm-guarding } \\
\text { Lady to Ms. Liang] }\end{array}$ & $\begin{array}{l}\text { Excerpt in Jianyan yilai xinian } \\
\text { yaolu, juan } 25,588 \text {. }\end{array}$ \\
\hline ca. 1240 & $\begin{array}{l}\text { Letter Responding to Yang [in Charge of] the } \\
\text { Branch Secretariat 答楊行省書 }\end{array}$ & $\begin{array}{l}\text { Zhanran jushi ji 湛然居士文集 } \\
\text { (Beijing: Zhonghua shuju, } \\
\text { 1986), 336. }\end{array}$ \\
\hline ca. 1380 & $\begin{array}{l}\text { Edit Appointing Shi Gui as the Female Prefect } \\
\text { qua Chieftain Official of Puding Command of } \\
\text { Sichuan 四川普定府土官女知府適貴誥文 }\end{array}$ & $\begin{array}{l}\text { Quan Yuan wen 全元文 (Nanjing. } \\
\text { Fenghuang chubanshe, 2004), } \\
\text { vol. 53, 13. }\end{array}$ \\
\hline 1383 & $\begin{array}{l}\text { [Edict Appointing Shang Sheng as Prefect of } \\
\text { Wuding Military and Civilian Command] }\end{array}$ & $\begin{array}{l}\text { Yunnan jiwu chao huang 雲南機 } \\
\text { 務抄黃, 275a. }\end{array}$ \\
\hline
\end{tabular}

Cite this article: Yin S (2022). Rewarding Female Commanders in Medieval China: Official Documents, Rhetorical Strategies, and Gender Order. Journal of Chinese History 6, 23-42. https://doi.org/10.1017/ jch.2021.20 